\title{
$70 \mathrm{MW}$ 級超電導発電機の界磁巻線の熱的安定性の検証
}

\begin{tabular}{|c|c|c|c|}
\hline 正員 & 下畑 & 賢司 & （三菱電機 \\
\hline 非会員 & 稲口 & 隆 & (三著整機 \\
\hline 正員 & 守田 & 正夫 & (三菱電機) \\
\hline 正員 & 中村 & 史朗 & (三菱電機) \\
\hline 正員 & 前田 & 進 & （三菱電機） \\
\hline 正員 & 鈴木 & 一市 & （三菱電機） \\
\hline 正員 & 平尾 & 俊樹 & (Super-GM) \\
\hline
\end{tabular}

Verification of thermal stability of the field coil for the 70MW class superconducting generator

Kenji Shimohata, Member, Takashi Inaguchi, Non Member, Masao Morita, Member, Shirou Nakamura, Member, Susumu Maeda, Member, Kazuichi Suzuki, Member

(Mitsubishi Electric Corporation)

Toshiki Hirao, Member

(Super-GM)

\begin{abstract}
Superconducting generators have many advantages such as increasing generation efficiency, improving power system stability and reducing size and weight in comparison with conventional generators. 70MW class superconducting generators are being developed in Japan to verify the basic technologies for a 200MW class superconducting pilot generator. Manufacture of 70MW slow response excitation type rotor has begun in 1992 and factory tests were conducted in 1996. Succeeding to the factory tests, the rotor was combined to the stator with air gap windings in the verification test facility in Osaka power station and verification tests were conducted in 1998. The advantages and the reliability of superconducting generators have been clarified in these tests.

In this paper, experimental results and analysis of the stability of the superconducting field windings at two kinds of severe tests; a continuous pulse excitation test and a sudden short circuit test are discussed. The main results are summarized as follows.
\end{abstract}

(1) Any quench has not occurred in the severe tests.

(2) A calculation method for the temperature rise of the conductor and the helium is developed in order to explain the experimental results. The calculated results agree well with the experimental ones.

キーワード : 超電導発電機、回転子、超電導界磁巻線、クエンチ、交流損失

\section{1.まえがき}

界磁巻線を超電導化した超電導発電機は、効率向上、電 力采統の安定性向上といった利点があり、研究開発が行わ れている。現在、通商産業省工業技術院のニューサンシャ イン計画、「超電導電力応用技術開発」の一環として 1988 年度からの 12 年計画により、200MW 級パイロット機の設 計・製作に必要な技術開発を目的とした「70MW 級モデル発 電機」（以下 70MW 級機上略記）の開発が進められている (1)

この計画において、筆者らは低速応型超電導発電機の開 発を担当しており、要㭟技術開発および「ロータ部分モテ

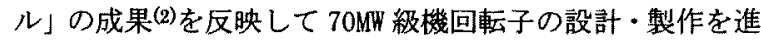

め、1996 年度に工場での回転励磁試験を行った(3)。 また、1998 年 3 月から 9 月にかけてステータと組み合 わせた現地実証試験を超電導組合試験センタ（関西電力 （株）大阪発電所構内）で実施した。現地実証試験におい て、超電導発電機としての基本特性検証試験、世界最大の $79.7 \mathrm{MW}$ の発電試験、世界最長の 1500 時間連続運転試験、 過酷試験として連続パルス励磁試験や三相突発短絡試験な どの全試験項目を成功裏に完了した(4)(5)。

本報告では、現地実証試験の連続パルス励磁試験および 突発短絡試験の試験結果に基づき、超電導界磁巻線の熱的 安定性を解析した結果について報告する。 


\section{2. $70 \mathrm{MW}$ 級モデル機の仕様}

表 1 に、70MW 級モデル機の主な設計諸元を示す。図 1 に、回転子の断面図を示す。回転子は超電導界磁巻線を液 体へリウムで極低温に泠却するため、真空断熱層を設けた 多重円筒構造である。回転時は遠心力により円筒状のヘリ ウム液面が形成される。界磁巻線は片極あたり 5 個のコイ ルを直列接続したものであり、それぞれのコイルは巻線取 付軸のスロットに納めている。図 2 に、超電導導体の模式 図を示す。超電導導体は、過渡時の交流損失での温度上昇 によるクエンチを防止するため $\mathrm{Cu} / \mathrm{CuNi} / \mathrm{NbTi}$ の 3 層構造 素線を 9 本撚り合わせたもので、磁界変化率 $5 \mathrm{~T} / \mathrm{s}$ におけ る導体の交流損失計算値は $50 \mathrm{~kW} / \mathrm{m}^{3}$ である。導体絶縁は 超電導導体にポリイミドテープを巻いた上に、プリプレグ 絶縁テープをスパイラル状にすかせ巻きして冷却流路を設 けている。界磁巻線を強固に固定するため、巻線後にプリ プレグ絶縁テープの樹脂を加熱硬化して導体相互を接着し ている。

\section{3. 連秸パルス励磁試験}

〈3. 1 試験結果〉連続パルス励磁によるクエンチ試 験は、パルス励磁時の損失でヘリウム槽内の圧力を上昇さ せ、へリウム温度と巻線温度を上昇させ、クエンチ発生を 試みる試験である。図3に、70MW級モデル機の界磁巻線 のロードライン、定格出力ポイントおよび連続パルス励磁 試験時の最大通電ポイントを示す。過酷試験に先立って実

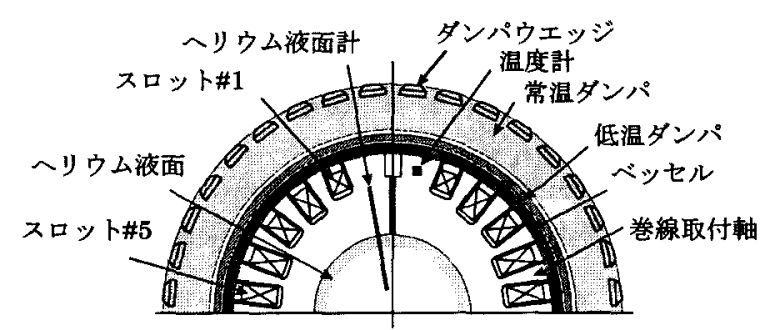

図 $170 \mathrm{MW}$ 級機の回転子の断面図

Fig.1. Schematic drawing of the transverse cross section of the rotor for the $70 \mathrm{MW}$ machine.

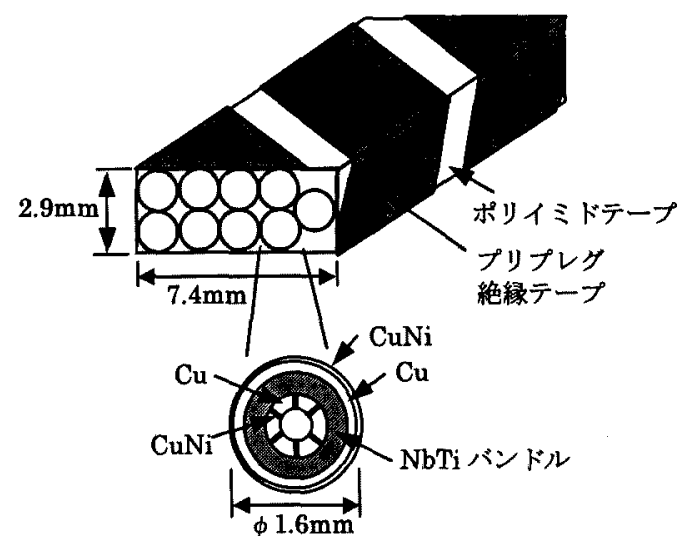

図 2 超電導導体の模式図

Fig.2 Schematic drawing of the conductor
表 $170 \mathrm{MW}$ 級機の諸元

Table 1 Main parameters of the 70MW machine

\begin{tabular}{|c|c|}
\hline \multicolumn{2}{|l|}{ 発央機 } \\
\hline 容量 & 83 MVA \\
\hline 電圧 & $10 \mathrm{kV}$ \\
\hline 奄流 & $4792 \mathrm{~A}$ \\
\hline \multicolumn{2}{|l|}{ 回転子 } \\
\hline 回転速度 & $3600 \mathrm{rpm}$ \\
\hline 外径 & $890 \mathrm{~mm}$ \\
\hline \multicolumn{2}{|l|}{ 界磁巻線 } \\
\hline コイル数 & $5 /$ pole \\
\hline 長さ & $1900 \mathrm{~mm}$ \\
\hline インダクタンス & $0.5 \mathrm{H}$ \\
\hline 設計定格動作点 & $3000 \mathrm{~A} / 4.5 \mathrm{~T}$ \\
\hline 設計最大電流/磁界 & $3600 \mathrm{~A} / 5.4 \mathrm{~T}$ \\
\hline 速応励磁時励磁速度 & $300 \mathrm{~A} / \mathrm{s}(0.1 \mathrm{p} . \mathrm{u} / \mathrm{s})$ \\
\hline \multicolumn{2}{|l|}{ 素線 } \\
\hline 素線外径 & $1.6 \mathrm{~mm}$ \\
\hline フィラメント数 & $9 \mu \mathrm{m}$ \\
\hline ツイストピッチ & $16 \mathrm{~mm}$ \\
\hline $\mathrm{Cu} / \mathrm{CuNi} / \mathrm{NbTi}$ & $2 / 1 / 1$ \\
\hline 残留抵抗比 & 160 \\
\hline \multicolumn{2}{|l|}{ 䢙体 } \\
\hline 幅 & $7.4 \mathrm{~mm}$ \\
\hline 厚み & $2.9 \mathrm{~mm}$ \\
\hline 素線数 & 9 \\
\hline ッイストピッチ & $75 \mathrm{~mm}$ \\
\hline $\begin{array}{l}\text { 交流椇失 } \\
\text { 絶縁 }\end{array}$ & $\begin{array}{l}50 \mathrm{~kW} / \mathrm{m}^{3} \quad(5 \mathrm{~T} / \mathrm{s}) \\
\text { ポリイミドテーブとプリブレ } \\
\text { グ絶縁テーブのすかせ巻き }\end{array}$ \\
\hline
\end{tabular}

施した発電機としての基本試験の結果より、定格出力時の 電流は2696Aである。連続パルス励磁試験は、電流変化率 $690 \mathrm{~A} / \mathrm{s}$ で、定格電流2696Aから最大 $3226 \mathrm{~A}$ まで、電流変化 幅850Appの三角波状パルス励磁を連続12パルス(36.1秒) 継続した。この試験条件による損失は、励磁速度の仕様で ある300A/sで定格電流まで10秒間で上昇させる場合の約 20倍に相当する。図中に、推定した各温度に対する導体の $\mathrm{Ic}^{\left({ }^{(6)} \text { を示した。最大電流時の臨界温度は約 } 6.2 \mathrm{~K} て ゙ あ る 。 ~\right.}$

図4に、連続パルス励磁試験結果を示す。計測データと して、へリウム槽の圧力および巻線取付軸の温度を示す。 巻線取付軸の温度は、損失がほほゼロである磁極部で測定 しており、界磁巻線の周りの液体へリウム温度とほぼ同じ と考えられる。連続パルス励磁終了時の取付軸温度は5.2K

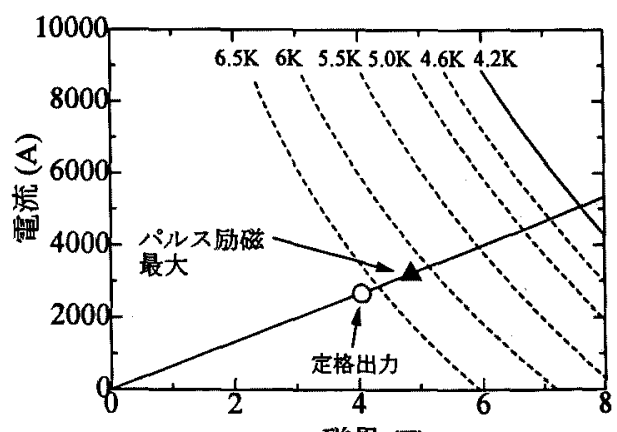

磁界 (T)

図 $370 \mathrm{MW}$ 級モデル機の界磁巻線のロードライン Fig. 3 Load line and critical currents of the rotor 


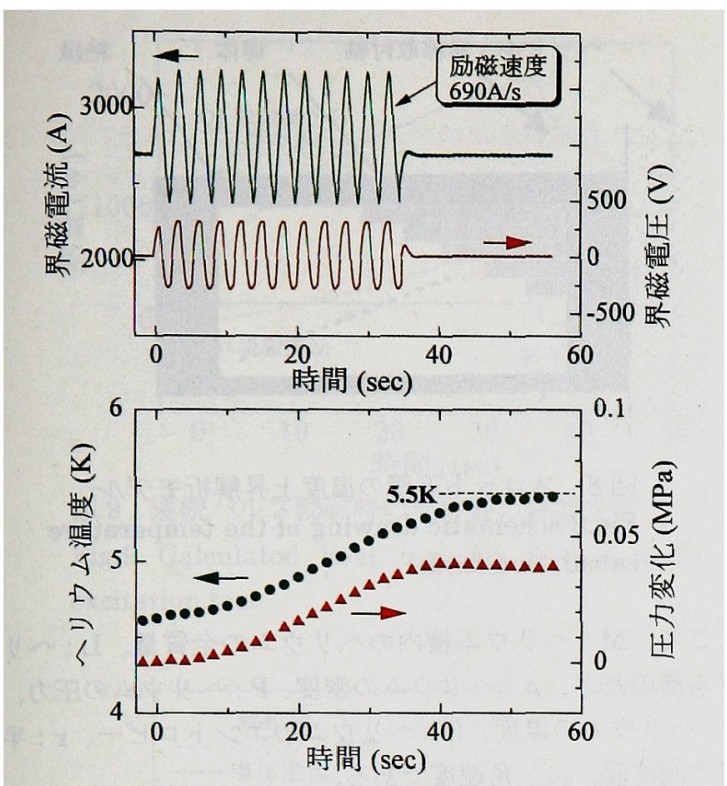

図 4 連続パルス励磁試験結果

Fig 4 Test results of the continuous pulse excitation

であり、その後最高5.5Kに達したが、界磁巻線にクエンチ は発生しなかった。

ワイヤモーション等による局所的発熱で発生する一般的 なクェンチに対しては、導体最高温度は $130 \mathrm{~K}$ 問題ないレ ベルであり、ヘリウム槽の圧力上昇は許容值2MPaに対し $1.3 \mathrm{MPa}$ と十分な強度を有している。しかし、ヘリウムの 温度上昇で界磁巻線の温度が均一に上昇して臨界温度に達 すると、両極の界磁巻線で同時にクエンチする確率が高ま る。この時、クエンチは両極の差電圧で検出しているため、 クエンチ検出と保護が遅れる可能性がある。さらに、界磁 巻線の温度が高い場合、常電導領域の伝播速度が早いため、 ヘリウム槽内で消費するエネルギが大きくなる。この時の 界磁巻線の最高温度・ヘリウム槽の最大圧力の制約から、 ヘリウムの最高温度を5.5Kに設定し、12パルスまでの試験 とした。

\section{〈3.2 導体温度計算方法〉}

\section{(1) 計算手順}

連続パルス励磁試験時には、界磁巻線、巻線取付軸、べ ッセル、ダンパに交流損失や渦電流損失などの損失が発生 する。界磁巻線や巻線取付軸の損失は、それらに蓄えられ るとともにヘリウムに入熱し、へリウム温度が上昇する。 また、界磁巻線の温度は、自身の損失や巻線取付軸からの 熱伝導によりへリウム温度から上昇する。これらを合わせ、 導体の温度上昇を計算した。計算手順は以下の通りである。

1. ヘリウムへの入熱によるへリウム温度の上昇 $(\delta \mathrm{T})$ を計算

2. ヘリウム温度 $(\mathrm{Tb})$ を一定とし、ヘリウム温度からの、

導体の温度上昇を計算 $(\Delta \mathrm{T})$

3.1,2より導体温度(Tcond)を計算 $(\mathrm{T}$ cond $=\mathrm{Tb}+\delta \mathrm{T}+\Delta \mathrm{T}$ )

電学論B, 120 巻 6 号, 平成 12 年

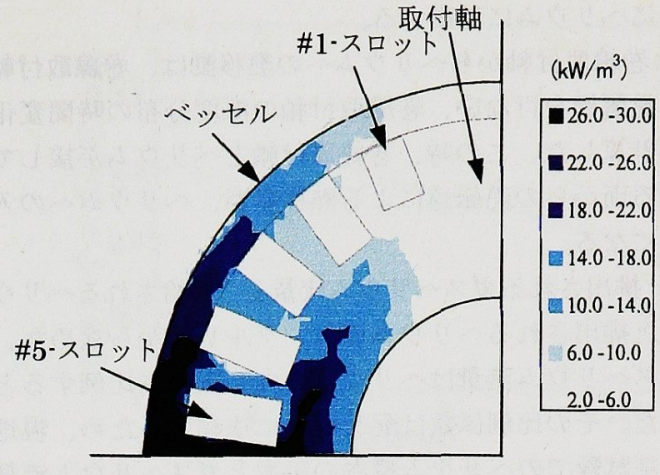

図 5 連続パルス励磁時の巻線取付軸での損失密度 Fig.5 Calculation result of the excitation loss at the support and vessel during the pulse excitation

(2) 損失

a. パルス励磁時の巻線取付軸、ベッセルでの損失

ノーダルネットワーク法を用いた 2 次元定常解析により 計算した。図5に、電流変化率が $690 \mathrm{~A} / \mathrm{s}$ の場合の巻線取付 軸执よびベッセルの損失密度を示す。\#5スロット近傍の損 失が最も大きく、最大損失密度は $29 \mathrm{~kW} / \mathrm{m}^{3}$ である。\#1スロ ット近傍の損失は $10 \mathrm{~kW} / \mathrm{m}^{3}$ 以下と小さい。

b. 導体の損失

磁界変化率 $5 \mathrm{~T} / \mathrm{s}$ (電流変化率 $3333 \mathrm{~A} / \mathrm{s}$ ) での交流損失は、 ヒステリシス損失に起因し電流変化率に比例する単位時間 あたりの損失を $9 \mathrm{~kW} / \mathrm{m}^{3}$ 、電流変化率の 2 乗に比例する結 合損失や渦電流損失を $41 \mathrm{~kW} / \mathrm{m}^{3}$ と見積もった。これから電 流変化率 $690 \mathrm{~A} / \mathrm{s}$ での単位時間あたりの導体の全交流損失 を $3.7 \mathrm{~kW} / \mathrm{m}^{3}$ とした。

連続パルス励磁中は電流変化率がほぼ一定のため、以下 の解析ではこれらの損失を一定とした。

(3)へリウムへの入熱

図 6 に、連続パルス励磁時の熱移動の模式図を示す。界 磁巻線加らの入熱 $(\mathrm{Q} 1) 、$ 巻線取付軸からの入熱 $(\mathrm{Q} 2) 、$ 系外 へ排出されるエネルギ(Q3)から、ヘリウムに加えられるエ ネルギ(Q)は以下で表せる。

$$
\mathrm{Q}=\mathrm{Q} 1+\mathrm{Q} 2-\mathrm{Q} 3
$$

ここで、各熱移動量は以下の条件で計算した。

Q1:界磁巻線はへリウム泠却流路を設けた構成であり、冷 却条件が良いため、界磁巻線で発生した熱量は速やか

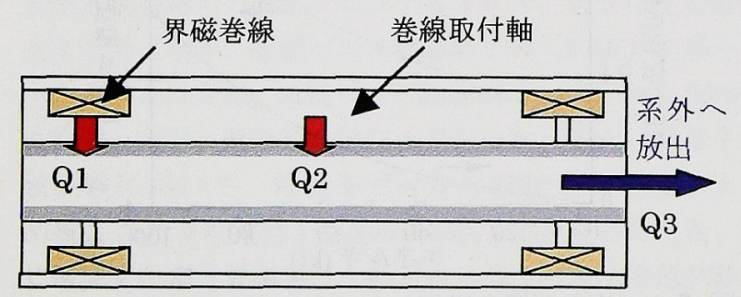

図 6 ヘリウム槽の熱移動の模式図

Fig.6 Schematic drawing of the heat transfer during continuous pulse excitation 
にヘリウムに移動する。

Q2: 巻線取付軸からへリウムへの熱移動は、巻線取付軸の

熱解析を行ない、巻線取付軸の温度分布の時間変化を 計算した。この時、巻線取付軸とへリウムが接してい る面からの熱伝達による熱移動が、ヘリウムへの入熱 になる。

Q3 : 排出されるガスヘリウム流量と、供給されるへリウム と排出されるへリウムのエンタルピ差から求めた。ガ スヘリウム流量はヘリウム槽内の圧力に比例するとし た。その比例係数は配管抵抗に依存するため、現地実 証試験でのへリウム槽内の圧力とガスヘリウム流量の 関係から求めた。

(4)ヘリウムへの入熱と温度・圧力

ヘリウム槽内の温度分布と圧力分布の計算方法は以下の 通りである(7)。へリウム槽内のへリウムの状態は液面（図 1）を境に $2 つ の$ 領域にわけることができる。液面の内側は ガスヘリウムで、外側は液体ヘリウムである。計算にあた り、以下の仮定を置いた。

試験時のへリウム液面はほぼ一定であったため

(1) ヘリウム槽のヘリウム量は変化しない。

とした。また、

(2) ヘリウムとヘリウム槽の周方向の角速度を同一とし、半 径方向および軸方向のへリウムの流れを無視する。

(3) 液面より内側の領域(ガスヘリウム)は飽和状態にある。

(4) 液面より外側の領域 (液体へリウム)のエントロピーは 半径方向に一定 (可逆断熱) である。

とした。上記仮定(1)と(2)から連続の式(1) 及び運動方程式 (2)は次のようになる。

$$
\begin{aligned}
& M=\int \rho(2 \pi r) d r \times L \\
& \frac{d P}{d r}=\rho r \omega^{2}
\end{aligned}
$$

また仮定(3)と(4)から次の状態方程式が得られる。

$$
\begin{aligned}
& P=P(T): \text { 液面より内側の領域 } \\
& \frac{d S}{d r}=0: \text { 液面より外側の領域 }
\end{aligned}
$$

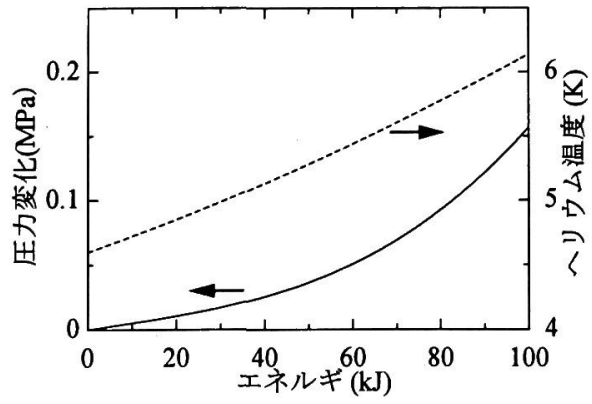

図 7 ヘリウム槽の増加したエネルギと圧力変化および ヘリウム温度の関倸

Fig.7 Increased energy dependence of the pressure change and helium temperature in the helium vessel

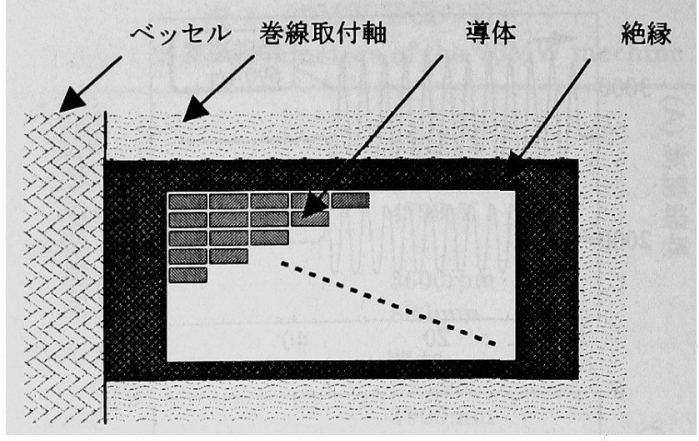

図 8 スロット近傍の温度上昇解析モデル

Fig. 8 schematic drawing of the temperature calculation model

ここで、 $\mathrm{M}$ : ヘリウム槽内のヘリウムの全質量、 $\mathrm{L}:$ : リ ウム槽の長さ、 $\rho:$ ヘリムム密度、P : ヘリウムの圧力、 $\mathrm{T}$ : ヘリウムの温度、 $\mathrm{S}:$ ヘリウムのエントロピー、 $\mathbf{r}$ : 半 径方向位置、 $\omega$ : 角速度である。

回転中心軸上のへリウムの圧力を境界条件にして式(1) 〜式(3) を解けばへリウムの圧力分布と温度分布が求まる。

ヘリウム槽内の全エネルギ E は、ヘリウムの内部エネル ギ、界磁巻線・巻線取付軸等構造材の内部エネルギからな る。ここで、ヘリウムの熱容量と比べ、界磁巻線・巻線取 付軸等構造材の熱容量は十分小さいためこの内部エネルギ を無視すると、ヘリウム槽内のエネルギは単位重量あたり の内部エネルギを e として以下で与えられる。

$$
E=\left[\int \rho e \cdot 2 \pi r d r\right] \times L
$$

ヘリウムへの入熱 $\mathrm{Q}$ が生じた場合、全エネルギ E'を次式 から計算する。

$$
E^{\prime}=E+Q
$$

全質量（M）が一定のまま、全エネルギ E が E’に一致す

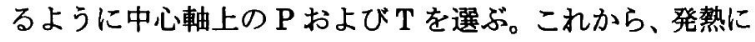
よるへリウム槽内の温度・圧力分布を求める。その結果を 図 7 に示す。例えばへリウムに 50kJ の熱が加えられた場 合、へリウム温度は $5.4 \mathrm{~K}$ に上昇し、内圧は $0.04 \mathrm{MPa}$ 上昇 する。

(5)ヘリウム温度からの界磁巻線温度上昇

巻線取付軸の発熱密度の大きい\#5 スロット近傍におい て、導体の損失、巻線取付軸やベッセルからの熱伝導、へ リウム冷却による導体の温度変化を計算した。図 8 にスロ ット近傍の温度変化計算モデルを示す。導体には、導体の 交流損失と巻線取付軸やベッセルからの伝導で伝わる熱が 加わる。へリウム温度は一定 (4.6 K) とし、ヘリウム泠却 の効果は、回転場での熱伝達(8)を用いヘリウム冷却流路と 素線間の隙間に存在するへリウムを考慮したモデルで、ロ ータ部分モデルのヒータクエンチ試験で検証した方法(2)を 用いた。

〈3. 3 計算結果〉図 9 に、連続パルス励磁時の熱移動 量の時間変化を示す。時間の経過と共に、巻線取付軸の温 


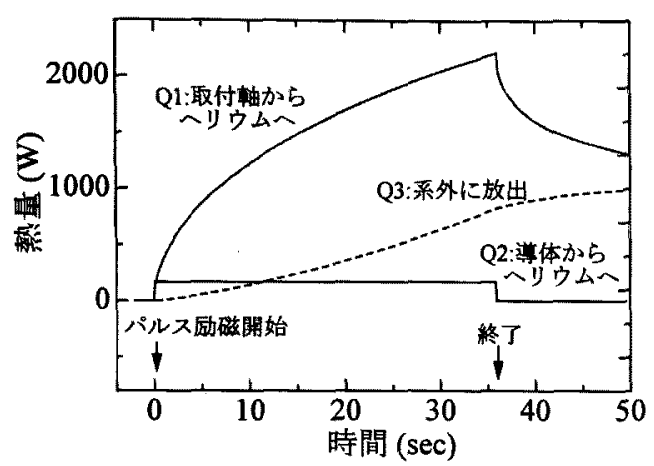

図 9 連続パルス励磁時の熱移動の時間変化

Fig.9 Calculated heat transfer during pulse excitation test

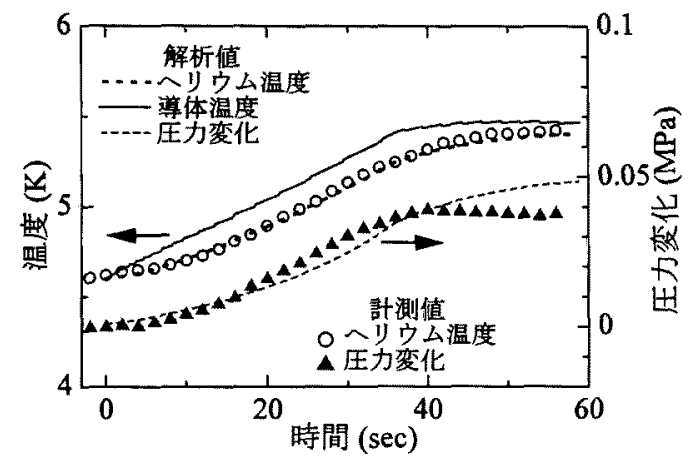

图 10 連続パルス励磁時の導体最高温度およひ ヘリウム槽内圧力変化の計算結果

Fig.10 Experimental results and calculated values of the helium temperature and pressure during pulse excitation

度上昇により巻線取付軸からへリウムへの熱移動が増加し、 内压の增加に伴い系外に放出される熱量も増加する。

図 10 に、ヘリウム温度およびヘリウム槽内の圧力変化 の計算結果を示す。パルス励磁継続中は、ヘリウム温度お よびへリウム槽内の圧力ともに上昇した。パルス励磁終了 後は、界磁巻線の損失は無くなるものの、巻線取付軸から ヘリウムへの熱移動が続くため、ヘリウム温度はなおも上 昇を続け、へリウム温度は最高 $5.5 \mathrm{~K}$ となった。へリウム 温度および圧力変化の計算結果は試験結果とほほ一致し、 計算の妥当性が確認できた。導体最高温度は、パルス励磁 終了時に最も高く、最高 $5.5 \mathrm{~K}$ となった。

〈3.4 考察〉連続パルス励磁において、界磁巻線の 温度マージン（臨界温度とへリウム温度の差）は初期の $1.6 \mathrm{~K}$ から $0.7 \mathrm{~K}$ 几と半分以下に低下したが、界磁巻線は超 電導状態を維持した。その理由を以下の通り考察した。

超電導コイルの熱的安定性の指標である最小クエンチエ ネルギの計算には、ロータ部分モデルのヒータクエンチ試 験結果をもとに検証した回転場での熱的安定性解析方法を 用いた。熱擾乱は素線間滑りによる摩擦発熱を想定し、素 線の最小クエンチエネルギを以下の条件で計算した。

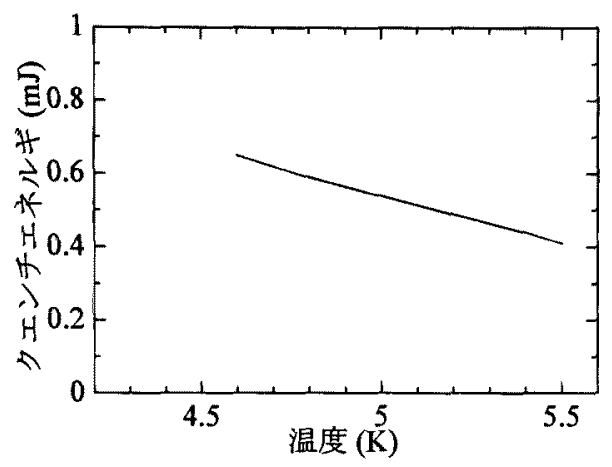

図 11 連続パルス励磁試験の最大電流時の最小 クエンチエネルギ計算結果

Fig.11 Temperature dependence of the calculated minimum quench energy at maximum current at pulse excitation test

表 2 連続パルス励磁時の最小クエンチエネルギ計算結果 Table 2 Calculated quench energy at pulse excitation

\begin{tabular}{|c|c|c|c|c|}
\hline $\begin{array}{l}\text { 界磁 } \\
\text { 電流(A) }\end{array}$ & $\begin{array}{l}\text { 温 度 } \\
(\mathrm{K})\end{array}$ & $\begin{array}{l}\text { Tcs } \\
\text { (K) }\end{array}$ & $\begin{array}{l}\text { 温度マー } \\
\text { ジン(K) }\end{array}$ & $\begin{array}{l}\text { 最小クエンチ } \\
\text { エネルギ(m })\end{array}$ \\
\hline \multicolumn{5}{|c|}{ パルス励磁開始時 } \\
\hline $\begin{array}{c}3226 \\
\text { パルス励磁終 }\end{array}$ & $\begin{array}{r}4.6 \\
\text { 了時 }\end{array}$ & 6.2 & 1.6 & 0.65 \\
\hline $\begin{array}{c}3226 \\
\text { 設計 (最大) }\end{array}$ & 5.5 & 6.2 & 0.7 & 0.41 \\
\hline 3600 & 4.6 & 5.8 & 1.2 & 0.35 \\
\hline
\end{tabular}

(1) 素線構成: 素線表面は厚み $60 \mu \mathrm{m}$ の CuNi で覆われて いる。秦線内部は素線表面の $\mathrm{CuNi}$ を除いた $\mathrm{Cu} / \mathrm{CuNi} / \mathrm{NbTi}$ の複合体で構成されており、その物性 值をそれらの平均值とした。素線内部の断面方向の温 度は一様とした。

(2)ヘリウムによる冷却 : 導体絶縁テープの冷却流路に存 在する液体へリウムと、素線間の隌間のへリウムによ る泠却を考虑した。

(3) 導体の初期温度 : 熱摄乱が加わる前の導体温度は、図 4 に対応して $4.6 \mathrm{~K}$ から $5.5 \mathrm{~K}$ まで変化させた。

（4）熱接乱 : 熱印加場所は素線表面の $\mathrm{CuNi}$ とし、擾乱長さ

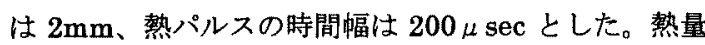
を変化させ、導体がクエンチする最小の熱量を求め、 それを最小クエンチエネルギとした。

図 11 に、温度を変えた場合の連続パルス励磁試験の最 大界磁電流時での最小クエンチエネルギ、表 2 に主な結果 をまとめて示す。連続パルス励磁終了時 $(5.5 \mathrm{~K})$ の最小ク エンチエネルギは、連続パルス励磁前 (4.6K) から $30 \%$ 程 度低下したが、設計時の値以上であった。また、回転子単 独試験において、電流をゼロから設計最大電流以上の $3780 \mathrm{~A}$ まで平均電流上昇速度 $660 \mathrm{~A} / \mathrm{s}$ で上昇させた後、同 じ電流変化率で界磁電流を低下させる 1 パルス励磁試験を 実施した結果、超電導状態を稚持することを確認しており、 ワイヤモーション等で発生する熱擾乱は $0.35 \mathrm{~mJ}$ 以下と考 えられる。これらから、連続パルス励磁による導体温度の 


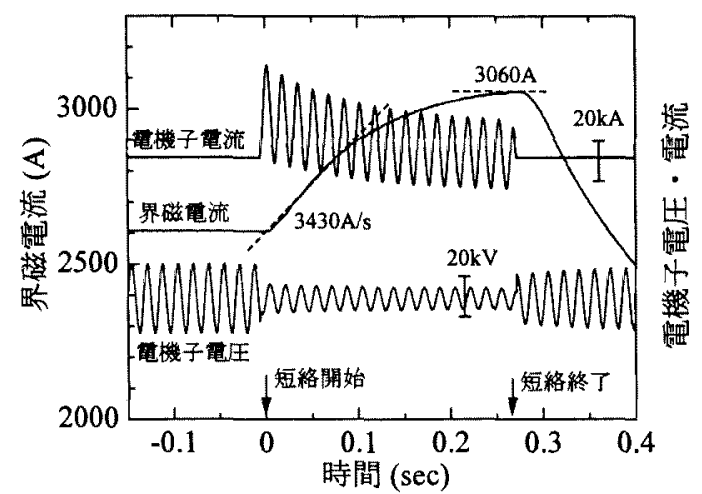

図 12 突発短絡試験時の界磁電流および電機子電 圧・電機子電流

Fig.12 Test result of the field coil and armature coil during the sudden short circuit test

上昇で、界磁巻線の温度マージンは設計より小さい值とな ったが、最小クエンチエネルギは熱損乱以上であったため クエンチに至らなかったと考えられる。

\section{4. 突発短絡試験}

〈4. 1 試験䊅果〉 電力系統で想定される事故として最 も過酷な主変圧器高圧側短絡事故を想定し、その条件と同 等の条件で突発短絡試験を赛施した。図 12 に突発短絡試 験時の電機子電圧、電機子電流および界磁電流を示す。電 機子電圧 $12 \mathrm{kV}$ 、界磁電流 $2614 \mathrm{~A}$ 加ら、電機子をリアクト ルで短絡した場合、界磁電流は最大 $3430 \mathrm{~A} / \mathrm{s}$ で上昇し、最 大 $3060 \mathrm{~A}$ となった。この時の最大界磁電流変化率は連続パ ルス励磁時の 5 倍であり、短時間ではあるが大きな損失が 発生したが、界磁巻線はクエンチせず安定であった。

〈4. 2 損失、温度解析方法〉突発短絡試験では、急激 な界磁電流の変化により巻線取付軸や導体に交流損失が発 生する。この損失による導体の温度上昇を、前項で示した 計算方法を用いて行った。なお、連続パルス励磁試験の計 算では電流変化率が一定のため損失も一定としたが、突発

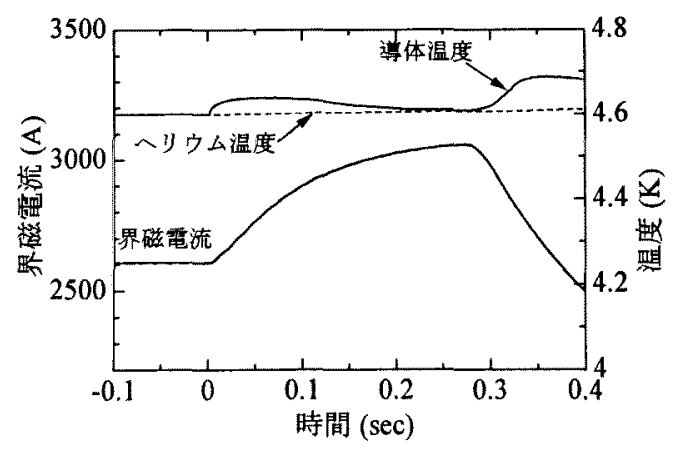

図 13 突発短絡試験時のヘリウム温度および導体 温度の計算結果

Fig.13 Current change of the Field coil and calculated temperature of the helium and the conductor during the sudden short circuit test
短絡試験時の電流変化率は時間とともに変化するため、こ れを考㦄した。

〈4. 3 胡算結果および考察〉図 13 に、突発短絡試験 時のヘリウム温度および導体温度の計算結果を、界磁電流 とともに示す。へリウム温度は、ほとんど上算しなかった。 突発短絡発生時に電流変化が最も大きい場合の導体温度上 昇は $0.04 \mathrm{~K}$ 、界磁電流が最大時の場合の導体温度上昇は $0.01 \mathrm{~K}$ であり、温度マージンと比較して十分小さい值であ った。突発短絡試験で発生したトルク変動に対しても、界 磁巻線にクエンチに至る熱拱乱は発生しなかったと考えら れる。

\section{5. 結論}

70MW 級超電導発電機の現地実証試験において、過酷試験 として連続パルス励磁によるクエンチ試験および突発短絡 試験を実施した。それら試験時の界磁巻線温度を、へリウ ムの温度上昇を考虑した計算を行なった。主な結果は次の 通りである。

（1）連続パルス励磁によるクエンチ試験および突発短絡試 験を含むいずれの試験においても、クエンチは発生し なかった。

(2) 連続パルス励磁によるへリウムの温度上昇計算結果は、 試験結果と良く一致した。界磁巻線温度は臨界温度以 下であり、妥当であった。これにより、界磁巻線や人 リウムの温度上昇を解析する手法を確立した。この手 法は他の超電導発電機にも適用可能であり、その熱的 安定性を予測することができる。

本研究は、通商産業省工業技術院のニューサンシャイン 計画「超電導電力応用技術開発」の一環として、新エネル ギ・産業技術総合開発機構（NEDO）からの委託により実 施したものである。

(平成 11 年 12 月 17 日受付、平成 12 年 02 月 25 日再受付)

文献

(1) T.Shimada, M.Shibuya, R.Takahashi, Y.Imai, H.Kusafuka, R.Shiobara, K.Yamaguchi, M.Takahashi, K.Suzuki, and K.Miyaike, "Recent Progress on 70MW Class Superconducting Generators", IEEE Transactions on Applied superconductivity, Vol.9, No.2, 1999, p.1189

(2) K. Shimohata, M. Morita, H. Yoshimura, T. Hirao, K. Suzuki, A. Ueda and K. Toyoda, "Normal Propagation Velocity and Quench Energy of the Rotor Model for a 70 MW class Superconducting Generator", IEEE Transactions on Applied superconductivity, Vol.7, No.2, 1997, pp.175

(3) K. Shimohata, I.Kodera, M. Morita, T.Inaguchi, H. Yoshimura, S.Nakamura, S.Maeda, K. Suzuki, A. Ueda and T. Hirao, "Cryogenic and Electrical Performance at 
a Factory Test of a Rotor for 70 MW Class Slow-Response Excitation Type Superconducting Generator", IEEE Transactions on Applied superconductivity, Vol.9, No.2, 1999, p.1213

（4）前田、增永、鈴木、上田、米谷、下畑、平尾 “ $70 \mathrm{MW}$ 級低 速応型超電導発電機の電気特性”電学論 Vol.119-B, No.11, pp1270-1276, 1999

(5) T.Hirao, H.Kusahuka, M.Shibuya, T.Shimada, K.Suzuki, A.Ueda, R.Shiobara, "Verification Test Results of 70MW Class of Slow- response Type B Superconducting generator" IEEE Power Engineering Society, Winter meeting, New York (USA), pp41-46, 1999

(6) M.N.Wilson "Superconducting Magnets", Clarendon Press Oxford, pp73, 1983

(7) T.Inaguchi, H.Yoshimura, T.Hirao, K.Suzuki, A.Ueda, "Analysis of Transitional Change in Pressure After Quench in Superconducting Generator", Proceedings of International Conference on Power Engineering-97, Vol.2, 1997, pp 47

（8)石井、新井、海保、桶口、野村、立石、大西”遠心力場にお ける液体へリウムの沸腾熱伝達”, 低温工学 Vol.26 No.4 (1991) pp77

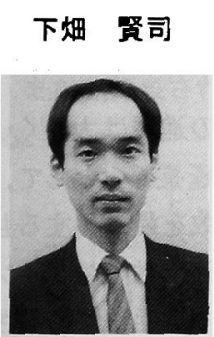

（正員）1962 年 5 月 18 日生。1987 年 大阪大学大学院理学研究科物理専攻修 士課程修了。同年 4 月三菱電機（株） 入社。主として超電導マグネットの開 発に従事。現在、先端技術総合研究所 勤務。

稆口 隆

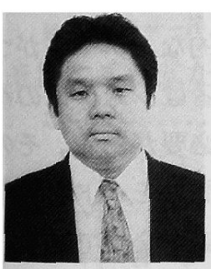

守田 正夫

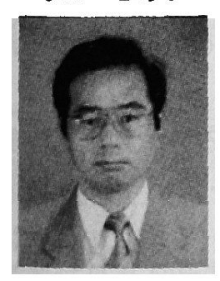

1961 年 3 月 3 日生。1986 年京都大学大 学院工学研究科航空工学専攻修士課程 修了。同年 4 月三菱電機（株）入社。 主として小型冷涷機、超電導マグネッ 卜の開発に従事。現在、先端技術総合 研究所勤務。

（正員）1956 年 7 月 10 日生。1975 年 3 月岡山県立笠仙工業高等学校卒業。同 年 4 月三菱電機（株）入社。主として 超電導マグネットおよびモータの開発 に従事。現在、先端技術総合研究所勤 務。
中村 史郎

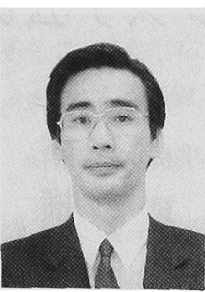

（正員）1949年 1 月 13 日生。1972 年 3 月九州大学工学部電気工学科卒業。同 年 4 月三菱電機（株）入社。主として 電磁界解析、超電導応用、ビーム応用、 加速器の研究に従事。現在、先端技術 総合研究所電機システム技術部部長。 工学博士。

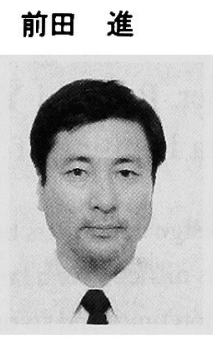

（正員）1952 年 10 月 1 日生。1977 年 北海道大学大学院工学研究科電気工学 専攻修士課程修了。同年 4 月三菱電機 (株) 入社。主としてタービン発電機、 超電導発電機の開発に従事。現在、電 力産業システム事業所勤務。1997 年日 本電機工業会電機工業技術功績者会長 賞受賞。

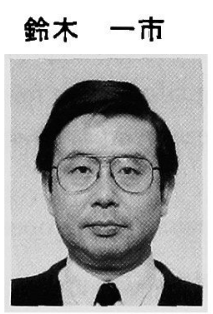

（正員）1952 年 1 月 14 日生。1976 年 名古屋大学大学院工学研究科電気工学 専攻修士課程修了。同年 4 月三菱電機 (株) 入社。主としてタービン発電機、 超電導発電機の開発に従事。現在、電 力産業システム事業所勤務。1997 年日 本電機工業会電機工業技術功績者会長 賞受賞。

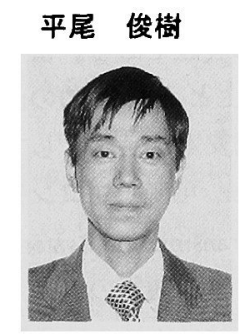

(正員) 1955 年 1 月 4 日生。1979年京 都大学大学院工学研究科電気工学専攻 修士課程修了。同年 4 月三菱電機（株） 入社。主としてタービン発電機、超電 導発電機の開発に従事。1997 年10 月か ら超電導発電関連機器 - 材料技術研究 組合に出向。 